\title{
PENGARUH IKLIM KOMUNIKASI ORGANISASI TERHADAP KINERJA APARATUR DI PEMERINTAHAN DESA
}

\author{
Influencing of Organizational Climate Communication to Job Performance in Situ Udik Rural \\ Government
}

\author{
Ahmad Fauzi*) dan Sarwititi Sarwoprasodjo \\ Departemen Sains Komunikasi dan Pengembangan Masyarakat, Fakultas Ekologi Manusia, IPB \\ *)Email : fauziahmadfauzi92@gmail.com
}

\begin{abstract}
The demand for public service that meet the needs of society now increasingly become an issue which continue to grow. The research was purposed to analyze organizational climate communication, implementation of good governance practice, job's performance, and the influence of organizational climate communication itself toward apparatus job performance in Situ Udik Rural Government. The research lead by quantitative approarch and supported by qualitative approach to the 69 respondents through census research method. The result indicates that organizational climate communication influence significantly toward job's performance, particularly on the variabel of openness in downward communication, listening in upward communication, participative decision making, concern for high performance goals, and trust. Aspect of good governance's implementation influence significantly toward job's performance in all repectively variables (transparency, accountability, and terms of law). According to the regression statistical analyze test result with alpha score $<$ 0.05 indicates that organizational climate communication influence 33.8 percent to describe job s performance and the implementation of good governance practices influence 16.9 percent to describe job 's performance.
\end{abstract}

Keywords: communication climate, good governance, job performance

\begin{abstract}
ABSTRAK
Permintaan terhadap pelayanan umum guna memenuhi kebutuhan masyarakat saat ini semakin menjadi isu yang semakin berkembang. Penelitian ini bertujuan untuk menganalisis iklim komunikasi organisasi, menganalisis praktik penerapan tata kelola pemerintahan yang baik, kinerja aparatur, dan menganalisis pengaruh iklim komunikasi terhadap kinerja aparatur di lingkungan Pemerintahan Desa Situ Udik. Penelitian ini menggunakan pendekatan kuantitatif dan didukung oleh pendekatan kualitatif untuk 69 responden melalui metode penelitian sensus. Hasil penelitian menunjukkan bahwa Iklim komunikasi organisasi berpengaruh signifikan terhadap kinerja aparatur, terutama pada variabel kepercayaan, pembuatan keputusan bersama, keterbukaan dalam komunikasi ke bawah, mendengarkan dalam komunikasi ke atas. Aspek penerapan tata kelola pemerintahan yang baik berpengaruh signifikan terhadap kinerja aparatur pada seluruh variabel (keterbukaan, tanggung jawab, dan hukum). Berdasarkan hasil uji analisis regresi statisti, nilai alpha $<0.05$ yang menunjukkan bahwa iklim komunikasi organisasi berpengaruh 33.8 persen terhadap kinerja aparatur dan praktik peneraan tata kelola yang baik berpengaruh 16.9 persen terhadap kinerja aparatur.
\end{abstract}

Kata kunci : iklim komunikasi, kinerja aparatur, tata kelola yang baik

\section{PENDAHULUAN}

Penerapan kebijakan desentralisasi yang dipahami sebagai penyerahan wewenang pemerintahan oleh pemerintah pusat kepada daerah otonom untuk mengatur dan mengurus urusan pemerintahan tercantum dalam sistem Negara Kesatuan Republik Indonesia menurut UU Nomor 32 Tahun 2004 tentang Pemerintahan Daerah. Lebih lanjut lagi, dibentuknya otonomi ini bertujuan untuk efisiensi pelayanan publik, efektivitas penyelenggaraan pemerintahan, dan pengembangan sistem demokrasi, serta sebagai alat untuk pembangunan pertumbuhan ekonomi yang lebih baik (Djohan, 2012). Fungsi pemerintahan daerah ini jelas mengarah pada efisiensi dan efektivitas penyelenggaraan pemerintahan yang merupakan organisasi berbasis pelayanan publik.

Pentingnya organisasi pelayanan publik mengacu pada Keputusan Menteri Negara Pendayagunaan Aparatur Negara No 63/KEP/M.PAN/7/2003 menyatakan bahwa dalam menghadapi era globalisasi, aparatur negara dalam hal ini dititikberatkan pada aparatur pemerintah hendaknya memberikan pelayanan yang sebaik-baiknya, berorientasi pada kebutuhan dan kepuasan penerima pelayanan, sehingga dapat meningkatkan daya saing dalam pemberian pelayanan. Pemerintah daerah di seluruh Indonesia selain memiliki peran yang lebih besar dalam mengelola daerah sebagaimana yang amanatkan dalam peraturan di atas 
juga dituntut untuk melaksanakan tanggung jawab secara maksimal. Walaupun demikian, pemerintahan daerah diharapkan mampu mengembangkan kapasitas kinerja yang optimal berdasarkan sumberdaya manusia yang dimilikinya.

Laporan dari Kementerian Pendayagunaan Aparatur Negara dan Reformasi Birokrasi (Menpan) pada tahun 2013 bahwa ada peningkatan yang signifikan pada tahun 2012 terhadap apa yang telah dilakukan penilaian akuntabilitas terhadap 435 (89 persen) dari 491 pemerintah kabupaten/kota. Hasilnya, sebanyak 106 kabupaten/kota atau hampir mencapai 25 persen jumlah kabupaten/kota yang berkinerja baik (mendapat nilai CC ke atas) serta dari hasil penilaian, dua kabupaten/kota diantaranya mendapat nilai $\mathrm{B}$, dibanding tahun sebelumnya hanya satu kota, adapun 104 lainnya mendapat nilai CC. Jika dilihat lebih cermat lagi, jumlah daerah yang memiliki nilai $\mathrm{CC}$ hampir sama dengan yang berkinerja baik. Artinya masih ada pekerjaan rumah yang harus diperbaiki mengenai kinerja pelayanan di pemerintahan daerah yang memiliki kriteria $\mathrm{CC}$ (memerlukan banyak perbaikan).

Masalah kinerja yang masih belum optimal ini diduga karena hubungan interaksi yang tidak solid di tubuh organisasi pelayanan publik. Interaksi yang di dalamnya terdapat peristiwa-peristiwa komunikasi ini jika dalam suasana mendukung akan menghasilkan kinerja yang baik dan optimal. Sebaliknya jika komunikasi yang berlangsung tidak mendukung, penurunan kinerja dapat saja terjadi. Kinerja dapat dianalisis dan diukur dari berbagai sudut pandang dan kebutuhan. Salah satu yang dapat mempengaruhi kinerja adalah iklim komunikasi organisasi. Iklim komunikasi organisasi menggambarkan suasana dan persepsi yang ditunjukkan oleh anggota organisasi dalam melakukan interaksi komunikasi kepada sesama ataupun pihak yang memiliki struktur yang lebih tinggi atau rendah terhadap dirinya.

Menurut hasil penelitian terdahulu dari Yoanne (2013) menunjukkan bahwa besar pengaruh iklim komunikasi organisasi PT. Djarum Super Cooking Oil Surabaya terhadap kinerja karyawan adalah 25.2 persen. Penelitian yang dilakukan oleh Gustiandri (2012) mengenai pengaruh iklim komunikasi organisasi terhadap kinerja Pegawai Direktorat Jenderal Pajak Serang menghasilkan temuan bahwa sebesar 44.3 persen variabel iklim komunikasi memiliki pengaruh terhadap variabel kinerja pegawai Direktorat Jenderal Pajak Pratama Kantor Pelayanan Pajak Serang. Beberapa hasil penelitian tersebut menunjukkan bahwa iklim komunikasi organisasi memberikan sumbangsih dalam mempengaruhi kinerja pegawai dalam suatu organisasi. Iklim komunikasi organisasi berkaitan dengan bentuk interaksi, persepsipersepsi, dan jaringan komunikasi internal organisasi yang mempengaruhi efektivitas fungsi organisasi.

Iklim komunikasi pada organisasi pelayanan publik penting untuk didukung oleh tata kelola atau manajemen yang baik pula. Manajemen pemerintahan daerah berkaitan dengan bagaimana pemerintahan daerah memiliki standar operasional yang terukur dan sesuai dengan visi dan misi daerah tersebut. Konsep good governance juga menjadi acuan untuk dapat melihat sejauh mana manajemen dan tata kelola pemerintahan daerah. Menurut Pohan (2000) dikutip Ambraw (2009) bahwa good governance tidak sebatas pada bagaimana pemerintah menjalankan wewenangnya dengan baik, tetapi yang lebih penting lagi adalah bagaimana masyarakat dapat berpartisipasi dan mengontrol pemerintah untuk menjalankan wewenangnya tersebut dengan baik. Kinerja atau performance menurut Bastaman (2010) adalah tingkat pencapaian yang dapat diukur dan dilihat dari kriteria dan standar yang telah ditetapkan oleh organisasi. Pemerintah sebagai organisasi publik dalam mewujudkan good governance membutuhkan kinerja optimal.

World Bank (2008) menetapkan empat pilar utama dalam menilai kinerja keseluruhan pemerintah daerah (pemda) yaitu, pengelolaan keuangan pemerintah, kinerja fiskal, penyediaan layanan, dan iklim investasi. Sebagai fokus bahwa tulisan ini mengacu pada kinerja pemerintah daerah (pemda) dalam penyediaan layanan publik seperti pendidikan, kesehatan, dan prasarana daerah.

Berbagai penelitian mengenai iklim komunikasi organisasi masih sebatas analisis pada lingkungan sebuah perusahaan, dinas-dinas pemerintahaan pusat atau pemerintahan pada tingkat kota/kabupaten. Interaksi komunikasi dalam keorganisasian di pemerintahan desa menjadi unik untuk dilihat bagaimana mereka dalam hal ini para aparatur menciptakan iklim komunikasinya sendiri.

Iklim komunikasi yang dibentuk dan didasari oleh nilai kekeluargaan atau kekerabatan yang mereka miliki tersebut membentuk perilaku dan tindakannya dalam menciptakan kinerja yang optimal terhadap publik. Pemerintahan Desa Situ Udik yang merupakan bagian dari organisasi pelayanan publik di pedesaan memiliki pengakuan yang positif mengenai kinerja dan penerapan good governance.

\section{Pertanyaan Penelitian}

Hal ini yang menjadi perhatian bagi peneliti untuk mengkaji: (1) Bagaimana keadaan iklim komunikasi yang berlangsung saat ini di Pemerintahan Desa Situ Udik? (2) Bagaimana pelaksanaan tata kelola yang saat ini diimplementasikan oleh Pemerintahan Desa Situ Udik? (3) Bagaimana kondisi kinerja aparatur publik saat ini di Pemerintahan Desa Situ Udik? (4) Bagaimana pengaruh iklim komunikasi terhadap kinerja aparatur di lingkungan Pemerintahan Desa Situ Udik?

\section{PENDEKATAN TEORITIS}

\section{Komunikasi Organisasi}

Komunikasi yang berlangsung di dalam organisasi menjadi bagian penting dalam keberlangsungan hidupnya sebuah organisasi. Menurut Pace dan Faules (2006) definisi komunikasi organisasi dibagi menjadi dua, yakni definisi fungsional dan definisi interpretatif, secara fungsional komunikasi organisasi dikatakan sebagai pertunjukan dan penafsiran pesan di antara unit-unit komunikasi yang merupakan bagian dari suatu organisasi tersebut sedangkan definisi secara interpretatif dari komunikasi organisasi adalah proses penciptaaan makna atas interaksi yang menciptakan, memelihara, dan mengubah organisasi.

Komunikasi organisasi mencakup proses interaksi yang terjadi pada orang-orang yang menjadi bagian dalam organisasi tersebut, sehingga komunikasi organisasi dapat menjadi suatu cara untuk mengidentifikasikan budaya kerja anggota dalam organisasi tersebut. Konteks komunikasi organisasi lebih spesifik dari konteks komunikasi secara 
umum. Komunikasi formal pada komunikasi organisasi dicirikan pada komunikasi menurut struktur organisasi (komunikasi ke atas, ke bawah, dan horizontal), sedangkan komunikasi informal lebih tidak melibatkan pada struktur organisasi seperti komunikasi sesama dalam konteks pertemanan atau rekan kerja.

\section{Iklim Komunikasi Organisasi}

Iklim komunikasi organsasi menurut Pace dan Faules (2006) adalah gabungan dari persepsi-persepsi mengenai peristiwa komunikasi, perilaku manusia, respon anggota terhadap anggota lainnya, harapan-harapan, konflikkonflik antar personal, dan kesempatan bagi pertumbuhan dalam organisasi tersebut. Iklim di sini merupakan suatu bentuk kiasan yang menggambarkan keadaan internal dan eksternal suatu organisasi yang di dalamnya mampu mempengaruhi beberapa hal. Denis dikutip Masmuh (2010) mengemukakan iklim komunikasi sebagai kualitas pengalaman yang bersifat objektif mengenai lingkungan internal organisasi, yang mencakup persepsi anggota organisasi terhadap pesan dan hubungan pesan dengan kejadian yang terjadi di dalam organisasi. Iklim komunikasi dapat menjadi dasar pula dalam menilai bagaiamana kualitas hubungan antar pegawai atau pegawai dengan atasannya dalam sebuah perusahaan.

Pace dan Faules (2006) menyatakan bahwa paling sedikit ada enam indikator besar dalam menilai iklim komunikasi organisasi. Enam indikator tersebut adalah kepercayaan (trust), kejujuran (honesty), pembuatan keputusan bersama (participative decision making), keterbukaan terhadap komunikasi ke bawah (openness in downward communication), mendengarkan dalam komunikasi ke atas (listening in upward communication), perhatian pada tujuan-tujuan berkinerja tinggi (concern for high performance goals).

Penelitian dan kajian mengenai iklim komunikasi telah tersebar di berbagai subjek analisis. Penelitian Yoanne (2013) mengenai iklim komunikasi organisasi di PT. Djarum Super Cooking Oil Surabaya yang berpengaruh langsung terhadap kinerja pegawai perusahaan sebesar 25.2 persen. Sanusi (2012) dalam penelitiannya tentang pengaruh motivasi kerja dan iklim komunikasi organisasi terhadap komitmen keorganisasian menghasilkan temuan bahwa iklim komunikasi organisasi berpengaruh sebesar 22.6 persen terhadap komitmen keorganisasian yang didukung oleh variabel kepedulian pegawai atas tujuan kinerja tinggi. Penelitian yang dilakukan oleh Nurlita (2012) memberikan temuan bahwa iklim komunikasi berpengaruh terhadap motivasi dan kinerja para pegawai atau staf di Universitas Bhayangkara Surabaya sebesar 30.9 persen, variabel keterbukaan dalam komuniksi dan perhatian terhadap berkinerja tinggi memiliki nilai tertinggi dalam mempengaruhi motivasi dan kinerja tersebut.

\section{Organisasi Pelayanan Publik}

Organisasi pelayanan masyarakat (public service) lebih menekankan kepada mendahulukan kepentingan pulik, mempermudah urusan publik, mempersingkat waktu proses pelaksanaan publik dan memberikan kepuasan kepada publik (Mulyadi, 2013). Menurut Prasetyani (2009) organisasi pelayanan publik adalah pemberian pelayanan atau melayani keperluan orang atau masyarakat yang mempunyai kepentingan pada organisasi itu sesuai dengan aturan pokok atau tata cara yang telah ditetapkan.

Keputusan Menteri Pendayagunaan Aparatur Negara Nomor: KEP/25/M.PAN/2/2004 menyatakan bahwa pelayanan publik merupakan segala kegiatan yang dilaksanakan oleh penyelenggara pelayanan publik sebagai upaya pemenuhan kebutuhan penerima pelayanan, maupun dalam rangka pelaksanaan ketentuan peraturan perundangundangan.

\section{Konsep Kinerja}

Kinerja atau performance didefinisikan oleh menurut Mangkunegara (2005) dikutip Gustiandri (2012) menyatakan bahwa kinerja (performance) adalah hasil kerja yang dapat dicapai oleh seorang atau sekelompok orang dalam suatu organisasi sesuai dengan wewenang dan tanggung jawab masing-masing dalam rangka upaya mencapai tujuan organisasi yang bersangkutan secara legal, tidak melanggar hukum dan sesuai dengan moral ataupun etika.

Kinerja organisasi ialah gambaran mengenai bagaimana seorang (baik pimpinan maupun anggota) melakukan segala sesuatu yang berhubungan dengan suatu pekerjaan, jabatan atau peranan dalam organisasi (Ambraw, 2009). Suatu kinerja dapat diukur dan dinilai dengan berbagai metode sesuai dengan kebutuhan dan jenis organisasi yang ada. Pengukuran setiap organisasi memiliki standar pengukuran kinerja yang berbeda dan disesuaikan dengan tujuan organisasi yang bersangkutan.Berdasarkan Kep. Men. PAN No: 63 Tahun 2003 pada standar penilaian kinerja pelayanan publik membagi orientasi penilaian kinerja menjadi orientasi proses (prosedur, sarana, kompetensi, dan petugas) dan orientasi hasil (waktu, biaya dan produk).

\section{Konsep Tata Kelola Pemerintahan yang Baik (Good Governance)}

Istilah tata kelola yang baik atau dalam Bahasa Inggrisnya Good Governance seringkali dikaitkan pula dengan kinerja suatu pemerintahan. Good governance (tata kelola pemerintahan yang baik) diartikan sebagai penyelenggaraan pemerintahan negara yang solid dan bertanggung jawab, efisien, dan efektif dengan menjaga kesinergisan interaksi yang konstruktif di antara domaindomain negara, sektor swasta dan masyarakat LAN (2003) dikutip Gustiandri (2012). Good governance merupakan perwujudan pemerintahan yang dekat dengan yang diperintah, mampu menyediakan pelayanan bagi masyarakat lokal secara efisien, sehingga akan lebih responsibel, akuntabel, responsif terhadap permasalahan, tuntutan, keinginan dan aspirasi rakyat (Bastaman, 2010). Pohan (2002) dikutip Ambraw (2009) menyatakan dalam penerapan good governance setidaknya memiliki tiga unsur atau tiga tiang aspek yang dinilai yaitu: (1) Transparansi (transparency); (2) Akuntabilitas (accountability); (3) Partisipasi (participation). Menurut Rahman (2000) dikutip Bastaman (2010) memberikan empat unsur utama good governance yaitu akuntabilitas, kerangka hukum, informasi dan transparansi.

\section{PENDEKATAN LAPANGAN}

Metode yang digunakan dalam penelitian ini adalah metode penelitian sensus. Penelitian ini menggunakan pendekatan penelitian kuantitatif yang didukung oleh 
data-data kualitatif. Singarimbun dan Effendi (1989) menyatakan bahwa dalam upaya memperkaya data dan lebih memahami fenomena sosial yang diamati, terdapat usaha untuk menambahkan informasi kualitatif pada data kuantitatif.

Populasi dalam penelitian ini adalah seluruh perangkat Desa Situ Udik baik laki-laki maupun perempuan yang bekerja aktif saat penelitian dilakukan yang berjumlah 69 orang. Penelitian ini menggunakan data sekunder dan data primer. Data sekunder didapatkan dari studi literatur dari pihak-pihak yang berkaitan dengan lokasi dan tujuan penelitian, yaitu profil Desa Situ Udik, data struktur organisasi perangkat Desa Situ Udik, dan data profil perangkat Desa Situ Udik. Data primer diperoleh dari hasil pengambilan data langsung di lapangan melalui kuisioner dan wawancara mendalam kepada responden dan informan.

Data kuantitatif yang diperoleh akan dianalisis masingmasing variabel melalui tabel frekuensi untuk melihat kondisi pada masing-masing variabel. Untuk melihat pegaruh secara signifikan antar variabel independen dan dependen, maka digunakan uji statistik non-parametrik melalui uji regresi linear berganda. Uji regresi linear berganda digunakan untuk menguji pengaruh lebih dari satu variabel independen terhadap variabel dependen (Wijaya 2009). Uji statistik ini juga digunakan untuk menjelaskan ada atau tidaknya pengaruh antar variabel (independen dan dependen).

\section{GAMBARAN UMUM DESA DAN PEMERINTAHAN DESA SITU UDIK}

\section{Kondisi Umum}

Desa Situ Udik merupakan desa yang terletak di Kecamatan Cibungbulang, Kabupaten Bogor. Luas wilayah Desa Situ Udik membentang seluas 370 hektar. Jumlah penduduk Desa Situ Udik, Kecamatan Cibungbulang, Kabupaten Bogor menurut data pada tahun 2013 (Tabel 1) tercatat sebanyak 14500 orang.

Tabel 1. Jumlah dan Persentase Penduduk Desa Situ Udik Berdasarkan Jenis Kelamin pada Tahun 2013

\begin{tabular}{rlrr}
\hline No & Jenis Kelamin & \multicolumn{1}{c}{$\begin{array}{l}\text { Jumlah } \\
\text { (orang) }\end{array}$} & \multicolumn{1}{c}{$\begin{array}{c}\text { Persentase } \\
\text { (\%) }\end{array}$} \\
\hline 1 & Laki-laki & 7350 & 50.7 \\
2 & Perempuan & 7150 & 49.3 \\
Total & & 14500 & 100.0 \\
\hline
\end{tabular}

Mayoritas penduduk Desa Situ Udik memiliki jenjang pendidikan setara dengan SMP. Sarana dan prasarana yang tersedia di Desa Situ Udik telah cukup memadai, ditandai dengan ketersediaan jalan aspal desa sepanjang sepuluh $\mathrm{km}$ yang kondisinya masih cukup baik. Jalan kecil (gang) desa sepanjang 2,5 km mendapatkan program PNPM dan diimplementasikan dengan baik hingga ke pelosok desa.

\section{Pemerintahan Desa Situ Udik}

\section{Dasar Hukum}

Secara umum sebagai dasar kebijakan didalam melaksanakan tugas wewenang dan kewajiban,
Pemerintahan Desa Situ Udik berpedoman kepada berbagai ketentuan dan peraturan sebagaimana yang telah ditetapkan antara lain: (1) Peraturan Desa Situ Udik Nomor 5 Tahun 2008 tentang Pembentukan Lembaga Kemasyarakatan Desa; (2) Peraturan Desa Situ Udik Nomor 2 Tahun 2009 tentang Organisasi dan Tata Kerja Pemerintahan Desa Situ Udik; (3) Peraturan Kepala Desa Situ Udik Nomor 9 Tahun 2008 tentang Pembagian Tugas dan Fungsi Perangkat Desa Situ Udik Kecamatan Cibungbulang.

\section{Struktur Organisasi}

Struktur Organisasi dan tata kerja Desa Situ Udik Kecamatan Cibungbulang Kabupaten Bogor berpedoman kepada peraturan yang telah ditetapkan secara sah dalam Peraturan Daerah Kabupaten Bogor Nomor 09 Tahun 2004 tentang Desa di dalam Peraturan Desa Situ Udik Nomor 2 Tahun 2009 tentang Organisasi dan Tata Kerja Pemerintahan Desa Situ Udik. Adapun formasi struktur organisasi Pemerintahan Desa Situ Udik terdiri dari: (1) Kepala Desa; (2) Sekretariat desa yaitu unsur staf atau unsur pelayanan yang terdiri enam kaur (kepala urusan) yaitu, kaur pemerintahan, kaur ekonomi pembangunan, kaur kesra, kaur keuangan dan kaur umum; (3) Unsur pelaksana atau teknis; (4) Unsur Wilayah (RT dan RW); (4) Badan Pengawasan Daerah (BPD).

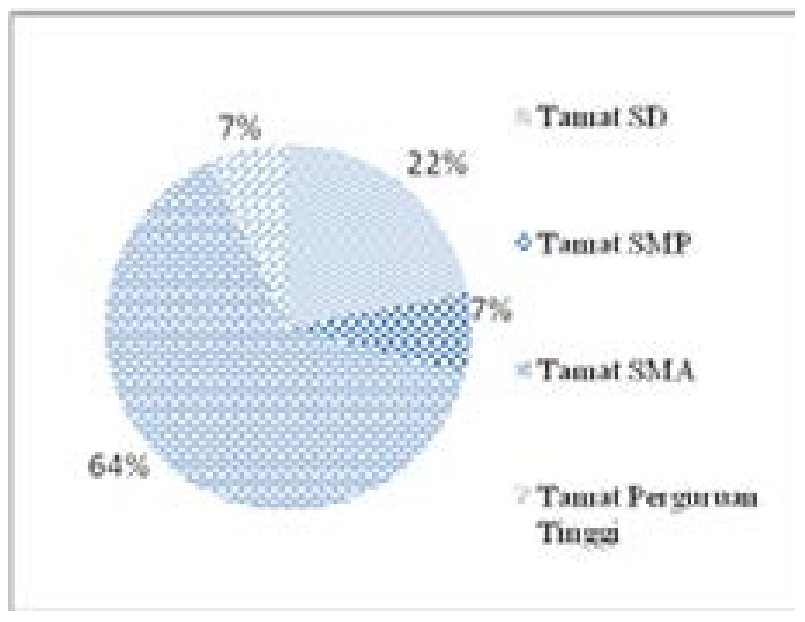

Gambar 1. Persentase jumlah Perangkat Desa Situ Udik Menurut Tingkat pendidikan

Jumlah kepala urusan sebagaimana yang dimaksud di atas disesuaikan dengan situasi dan kondisi yang didasarkan atas pertimbangan kebutuhan pelayanan personil dan kemampuan keuangan di Desa Situ Udik. Latar belakang pendidikan perangkat desa mayoritas tamatan SMA mencakup 64 persen dari jumlah anggota (Gambar 1). Secara umum tingkat pendidikan para perangkat desa (staf kantor desa dan kepala desa) lebih tinggi dari pada para Ketua RT dan RW. Lama bekerja perangkat desa rata-rata 12 tahun dengan rata-rata umur anggota yang berkisar 45 50 tahun.

Mulyana (2005) menjelaskan komunikasi organisasi terjadi dalam suatu organisasi, dapat bersifat formal dan juga informal, serta belangsung dalam suatu jaringan yang lebih besar dari pada komunikasi kelompok. Struktur organisasi pada Pemerintahan Desa Situ Udik juga menggambarkan bagaimana pola komunikasi yang berlangsung. Kepala desa sebagai pusat kegiatan komunikasi antara aparatur. 
Masing-masing staf kantor, Ketua RW dan Ketua RT dapat langsung berkomunikasi satu sama lain. Artinya komunikasi yang berlangsung tidak hanya topdown, melainkan dua arah. Masing-masing aparatur dapat memberikan krtitik atau nasehat kepada kepala desa dan begitu pun sebaliknya. Kepala desa memastikan tidak ada aparatur yang merasa segan untuk berkomunikasi dengannya, jadi kepala desa lebih menyukai pendekatan personal dan informal dalam berkomunikasi satu sama lain.

\section{HASIL PENELITIAN}

\section{Analisis Deskriptif Kondisi Iklim Komunikasi Organsiasi Pemerintahan Desa Situ Udik}

Variabel yang digunakan dalam mengukur kondisi iklim komunikasi organisasi pada Pemerintahan Desa Situ Udik dibagi menjadi lima, yaitu tingkat kepercayaan, tingkat pengambilan keputusan bersama, keterbukaan dalam komunikasi ke bawah, mendengarkan dalam komunikasi ke atas, dan perhatian terhadap tujuan berkinerja tinggi.

Tabel 2. Jumlah dan Persentase Aparatur Pemerintahan Desa Situ Udik Menurut Kondisi Iklim Komunikasi

\begin{tabular}{|c|c|c|c|}
\hline $\begin{array}{l}\text { Variabel iklim } \\
\text { komunikasi } \\
\text { organisasi }\end{array}$ & $\begin{array}{l}\text { Kate- } \\
\text { gori }\end{array}$ & $\begin{array}{l}\text { Jumlah } \\
\text { (orang) }\end{array}$ & $\%$ \\
\hline \multirow{4}{*}{$\begin{array}{l}\text { Tingkat keper- } \\
\text { cayaan }\end{array}$} & Rendah & 8 & 11.6 \\
\hline & $\begin{array}{l}\text { Se- } \\
\text { dang }\end{array}$ & 18 & 26.1 \\
\hline & Tinggi & 43 & 62.3 \\
\hline & Total & 69 & 100.0 \\
\hline \multirow{4}{*}{$\begin{array}{l}\text { Tingkat pembua- } \\
\text { tan keputusan } \\
\text { bersama }\end{array}$} & Rendah & 4 & 5.8 \\
\hline & $\begin{array}{l}\text { Se- } \\
\text { dang }\end{array}$ & 36 & 52.2 \\
\hline & Tinggi & 29 & 42.0 \\
\hline & Total & 69 & 100.0 \\
\hline \multirow{2}{*}{$\begin{array}{l}\text { Keterbukaan } \\
\text { dalam komuni- } \\
\text { kasi ke }\end{array}$} & Rendah & 7 & 10.1 \\
\hline & $\begin{array}{l}\text { Se- } \\
\text { dang }\end{array}$ & 32 & 46.4 \\
\hline \multirow[t]{2}{*}{ Bawah } & Tinggi & 30 & 43.5 \\
\hline & Total & 69 & 100.0 \\
\hline \multirow{2}{*}{$\begin{array}{l}\text { Mendengarkan } \\
\text { dalam komuni- } \\
\text { kasi }\end{array}$} & Rendah & 14 & 20.3 \\
\hline & $\begin{array}{l}\text { Se- } \\
\text { dang }\end{array}$ & 38 & 55.1 \\
\hline \multirow[t]{2}{*}{ ke atas } & Tinggi & 17 & 24.6 \\
\hline & Total & 69 & 100.0 \\
\hline \multirow{4}{*}{$\begin{array}{l}\text { Perhatian terha- } \\
\text { dap tujuan } \\
\text { berkinerja tinggi }\end{array}$} & Rendah & 19 & 27.5 \\
\hline & $\begin{array}{l}\text { Se- } \\
\text { dang }\end{array}$ & 32 & 46.4 \\
\hline & Tinggi & 18 & 26.1 \\
\hline & Total & 69 & 100.0 \\
\hline
\end{tabular}

Secara keseluruhan menunjukkan bahwa sebanyak 62.3 persen aparatur Pemerintahan Desa Situ Udik memiliki tingkat kepercayaan satu sama lain yang tinggi dalam hubungan komunikasinya. Artinya bahwa segala bentuk tindakan dan perilaku anggota komunikasi telah terkondisi dengan baik, sehingga persepsi yang ditimbulkan oleh masing-masing aparatur positif dan memiliki kecenderungan kecurigaan yang rendah.

Tingkat pembuatan keputusan bersama pada Pemerintahan Desa Situ Udik berlangsung sedang atau mencakup 52.2 persen dari seluruh anggota pemerintahaan desa. Sisanya sebesar 42 persen menganggap mereka selalu dilibatkan dalam pengambilan keputusan dan 5.8 persen yang menganggap mereka jarang hingga tidak pernah dilibatkan dalam pengambilan keputusan. Artinya bahwa Pemerintah Desa Situ Udik sudah cukup baik dalam membangun partisipasi anggotanya dalam pengambilan keputusan. Masing-masing aparatur merasa setiap terdapat pertemuan desa selalu diundang.

Secara umum, Pemerintahan Desa Situ Udik memiliki keterbukaan dalam komunikasi ke bawah yang cukup baik. Proporsi antara tingkatan tinggi dan sedang hampir berimbang. Hal ini menandakan bahwa sebesar 89.9 persen aparatur merasa tidak sulit untuk berkomunikasi kepada atasan jika terdapat hal yang ingin ditanyakan perihal administrasi maupun pelaporan lainnya dan aparatur mendapatkan informasi penugasan secara lengkap baik melalui surat maupun informasi langsung tatap muka.

Lebih dari setengah anggota Pemerintahan Desa Situ Udik memiliki tingkat mendengarkan dalam komunikasi ke atas yang sedang, namun jumlah anggota pemerintahan yang masuk kategori rendah juga cukup tinggi atau sebesar 20.3 persen. Hal tersebut harus menjadi perhatian penting karena kaitannya dalam membangun pemerintahan yang responsif dan fokus terhadap pelayan yang prima.

Secara umum tingkat perhatian terhadap tujuan berkinerja tinggi di aparatur Pemerintahan Desa Situ Udik masuk pada kategori sedang sebesar 46.4 persen. Masing-masing aparatur mengganggap perlu untuk melaksanakan tugas dengan sebaik-baiknya dalam memberikan pelayanan kepada warga maupun dalam melaporkan hasil kerja kepada kepala desa.

\section{Analisis Deskriptif Kondisi Pelaksanaan Good Governance di Pemerintahan Desa Situ Udik}

Variabel yang digunakan untuk menganalisis kondisi pelaksanaan tata kelola yang baik (good governance) pada Pemerintahan Desa Situ Udik adalah transaparansi, akuntabilitas, dan kerangka hukum. Hasil analisis deskriptif masing-masing variabel pelaksanaan good governance disajikan pada Tabel 3 .

Secara umum tingkat pelaksanaan transparansi di Pemerintahan Desa Situ Udik berjalan dengan baik dan masuk pada kategori tinggi (46.4 persen). Aparatur merasa perlu untuk mensosialisasikan informasi apapun yang berkaitan dengan kegiatan desa, menjelaskan prosedur pembuatan Kartu Tanda Penduduk (KTP), Kartu Keluarga (KK), atau surat administrasi lainnya.

Tingkat akuntabilitas di Pemerintahan Desa Situ Udik mayoritas persentase menunjukkan pada tingkat sedang. Persentase tingkat akuntabilitas tinggi juga memiliki nilai yang cukup tinggi dan sisanya sebesar 11.4 persen masih berkategori rendah. Pelaporan yang dilakukan oleh 
para Ketua RT dan Ketua RW dibagi menjadi dua yaitu lisan dan tertulis. Komunikasi lisan merupakan bentuk aktivitas akuntabilitas maupun transparansi yang dominan di lingkungan para Ketua RT dan Ketua RW sedangkan tertulis biasa digunakan ketika laporan tersebut perlu data arsip dokumentasi atau dalam rapat bulanan atau tahunan seperti musrembang.

Tabel 3. Jumlah dan Persentase Aparatur Pemerintahan Desa Situ Udik Menurut Pelaksanaan Good Governance

\begin{tabular}{llrr}
\hline $\begin{array}{l}\text { Variabel pelak- } \\
\text { sanaan good } \\
\text { governance }\end{array}$ & $\begin{array}{l}\text { Kate- } \\
\text { gori }\end{array}$ & $\begin{array}{r}\text { Jumlah } \\
\text { (orang) }\end{array}$ & \multicolumn{1}{c}{$\%$} \\
\hline Transparansi & Rendah & 8 & 41.6 \\
& $\begin{array}{l}\text { Se- } \\
\text { dang }\end{array}$ & 29 & 42.0 \\
& Tinggi & 32 & 46.4 \\
& Total & 69 & 100.0 \\
Akuntabilitas & Rendah & 8 & 11.6 \\
& Se- & 32 & 46.4 \\
& dang & & 42.0 \\
& Tinggi & 29 & 100.0 \\
& Total & 69 & 14.5 \\
Kerangka & Rendah & 10 & 60.9 \\
hukum & Se- & 42 & 24.6 \\
& dang & & 100.0 \\
\hline & Tinggi & 17 & \\
& Total & 69 & \\
\hline
\end{tabular}

Secara umum dapat dikatakan bahwa tingkat pemahaman dan kepatuhan hukum yang ada pada Pemerintahan Desa Situ Udik mayoritas (60.9 persen) pada kategori sedang. Hal ini berarti bahwa individu mayoritas paham dan patuh akan aturan-aturan dalam memberikan pelayanan kepada masyarakat, aparatur secara mayoritas menyatakan hukum yang ada merupakan hasil dari keputusan bersama dan sama sekali tidak memberatkan pekerjaan mereka.

\section{Analisis Deskriptif Kondisi Kinerja Aparatur di Pemerintahan Desa Situ Udik}

Variabel yang digunakan untuk mengukur kinerja diambil berdasarkan Kep. Men. PAN No: 63 Tahun 2003 tentang pedoman umum penyelenggaraan pelayanan publik pada poin standar penilaian kinerja pelayanan publik membagi orientasi penilaian kinerja menjadi orientasi proses (waktu, biaya dan produk) dan orientasi hasil (prosedur, sarana, kompetensi, dan petugas). Semua variabel memungkinkan untuk diukur berdasarkan temuan di lapang. Hasil analisis deskriptif mengenai variabel kinerja disajikan pada Tabel 4.

Kinerja yang ditunjukkan berdasarkan kesesuaian kerja menurut prosedur waktu secara mayoritas berada pada tingkat sangat sesuai. Para Ketua RT dan RW menunjukkan komitmen kerja sesuai dengan waktu yang ditetapkan, atau dengan kata lain ketika ada pertemuan rapat yang terencana maupun dadakan aparatur datang tepat waktu dan jika ada warga yang membutuhkan pelayanan administrasi atau pelayanan lainnya individu secara sigap melaksanakan tugasnya.

Tabel 4. Jumlah dan Persentase Aparatur Pemerintahan Desa Situ Udik Menurut Kondisi Kinerja

\begin{tabular}{|c|c|c|c|}
\hline $\begin{array}{l}\text { Variabel kin- } \\
\text { erja }\end{array}$ & Kategori & $\begin{array}{l}\text { Jumlah } \\
\text { (orang) }\end{array}$ & $\%$ \\
\hline \multirow{4}{*}{$\begin{array}{l}\text { Prosedur wak- } \\
\text { tu }\end{array}$} & Tidak sesuai & 6 & 8.7 \\
\hline & Cukup sesuai & 31 & 45.0 \\
\hline & Sangat sesuai & 32 & 46.3 \\
\hline & Total & 69 & 100.0 \\
\hline \multirow[t]{4}{*}{$\begin{array}{l}\text { Sarana dan } \\
\text { prasarana }\end{array}$} & $\begin{array}{l}\text { Kurang mema- } \\
\text { dai }\end{array}$ & 4 & 5.7 \\
\hline & Cukup memadai & 54 & 78.3 \\
\hline & Sangat memadai & 11 & 16.0 \\
\hline & Total & 69 & 100.0 \\
\hline \multirow[t]{4}{*}{ Kompetensi } & Rendah & 1 & 1.5 \\
\hline & Sedang & 23 & 33.3 \\
\hline & Tinggi & 45 & 65.2 \\
\hline & Total & 69 & 100.0 \\
\hline \multirow{4}{*}{$\begin{array}{l}\mathrm{W} \text { a } \mathrm{k} \mathrm{t} \text { u } \\
\text { penyelesaian }\end{array}$} & Lambat & 9 & 13.0 \\
\hline & Sedang & 51 & 74.0 \\
\hline & Cepat & 9 & 13.0 \\
\hline & Total & 69 & 100.0 \\
\hline \multirow{4}{*}{$\begin{array}{l}\text { Biaya penyele- } \\
\text { saian }\end{array}$} & Tidak sesuai & 12 & 17.3 \\
\hline & Cukup sesuai & 51 & 74.0 \\
\hline & Sangat sesuai & 6 & 8.7 \\
\hline & Total & 69 & 100.0 \\
\hline \multirow{4}{*}{$\begin{array}{l}\mathrm{P} \quad \mathrm{r} \text { o } \quad \mathrm{d} \quad \mathrm{u} \\
\text { penyelesaian }\end{array}$} & Tidak sesuai & 11 & 16.0 \\
\hline & Cukup sesuai & 36 & 52.0 \\
\hline & Sangat sesuai & 22 & 32.0 \\
\hline & Total & 69 & 100.0 \\
\hline
\end{tabular}

Secara umum sarana dan prasarana kerja pada Pemerintahan Desa Situ Udik masuk pada kategori sedang. Artinya bahwa aparatur secara mayoritas menilai sarana dan prasarana saat ini yang mereka pakai telah cukup memadai dalam menunjang pekerjaan. Selanjutnya, bagi di lingkungan para Ketua RT dan Ketua RW sarana dan prasarana ini lebih ditingkatkan pada sarana dan prasarana yang ada di kantor desa bukan pada dirinya. Ini berarti untuk menunjang pekerjaan mereka maka sarana dan prasarana kantor desa adalah kuncinya.

Sebesar 65.2 persen Pemerintahan Desa Situ Udik menunjukkan tingkat kompetensi yang tinggi. Bagi kepala desa pengevaluasian pekerjaan mutlak diperlukan dan hal ini juga dirasakan oleh staf kantor desa maupun para Ketua RT dan RW bahwa setiap pekerjaan mereka akan dikontrol oleh kepala desa. Para Ketua RT dan RW juga dapat memberikan teguran kepada kepala desa ketika melakukan kekeliruan kerja dan biasanya hal tersebut berlangsung dalam suatu pertemuan desa.

Pemerintahan Desa Situ Udik memiliki tingkat waktu 
penyelesaian pelayanan pada kategori sedang sebesar 74 persen. Artinya bahwa Pemerintahan Desa Situ Udik tidak terlalu cepat menyelesaikan pelayanan dan tidak terlalu lambat namun aparatur tetap berusaha untuk melakukan pekerjaan sesuai dengan prosedur. Persepsi biaya pelayanan secara umum pada Pemerintahan Desa Situ Udik berada pada kategori cukup sesuai atau sebesar 74 persen. Para aparatur desa merasa bahwa biaya ditetapkan secara bersama dan bukan suatu kewajiban bagi masyarakat untuk membayarnya. Pada dasarnya semua produk pelayanan publik adalah tidak dipungut biaya namun jika masyarakat ingin memberikan uang tersebut dapat mengacu pada nilai maksimal yang telah ditetapkan.

Tingkat produk pelayanan yang diberikan oleh Pemerintahan Desa Situ Udik sebesar 52 persen masuk pada kategori cukup sesuai. Artinya bahwa dalam kinerjanya saat ini dalam memberikan pelayanan kepada masyarakat produk-produk pelayanan dinilai telah sesuai dengan kebutuhan masyarakat, telah cukup mampu mengakomodir kepentingan masyarakat dan produk-produk pelayanan tersebut berjalan dengan baik. Produk pelayanan tidak terbatas itu-itu saja namun juga disesuaikan dengan program-program pemerintahan yang bertujuan untuk meningkatkan taraf hidup masyarakat desa.

\section{Analisis Pengaruh Iklim Komunikasi Organisasi terhadap Kinerja Aparatur}

Iklim komunikasi organisasi antar aparatur Pemerintahan Desa Situ Udik dilihat berdasarkan tingkat kepercayaan, pembuatan keputusan bersama, keterbukaan dalam komunikasi ke bawah, mendengarkan dalam komunikasi ke atas, dan perhatian terhadap tujuan berkinerja tinggi.

Masing-masing variabel tersebut dilihat hubungan atau pengaruhnya terhadap kinerja aparatur yang dihitung secara keseluruhan konsep kinerja yaitu prosedur waktu, sarana dan prasarana, kompetensi, waktu penyelesaian, biaya pelayanan, produk pelayanan. Sebagai variabel besar Y, kinerja dihitung secara agregat dari enam indikator yang dijelaskan sebelumnya. Pengujian iklim komunikasi organisasi terhadap kinerja pelayanan publik di Pemerintahan Desa Situ Udik dilakukan dengan analisis regresi linear berganda.

a) Collinearity statistics digunakan untuk uji asumsi klasik multikolinearitas yang berfungsi untuk melihat apakah terjadi multikolinearitas pada data yang diuji statistik. Multikolinearitas tidak terjadi jika nilai tolerance $>0.1$ dan nilai $\mathrm{VIF}<10$. Kolom collinearity statistics pada Tabel 5 menunjukkan pada data yang diuji tidak terjadi multikolinearitas.

*) Signifikan pada $\alpha<0.05$

**) Signifikan pada $\alpha<0.01$

Tabel 5 dapat dilihat dari nilai Adjusted $\mathrm{R}$ square menunjukkan angka 0.338. Maksudnya adalah sebesar 33.8 persen dari variance kinerja dapat dijelaskan oleh perubahan nilai variabel kepercayaan, pembuatan keputusan bersama, keterbukaan dalam komunikasi ke bawah, mendengarkan dalam komunikasi ke atas, dan perhatian terhadap tujuan berkinerja tinggi yang akan dijelaskan secara lebih rinci pengaruhnya dari tiap variabel. Nilai tersebut menyimpulkan bahwa kinerja aparatur di
Pemerintahan Desa Situ Udik sebesar 33.8 persen dapat dipengaruhi oleh iklim komunikasi organisasi.

Tabel 5. Hasil Uji Statistik Analisis Regresi Linear Berganda Pengaruh Iklim Komunikasi Organisasi Terhadap Kinerja Aparatur di Pemerintahan Desa Situ Udik

\begin{tabular}{|c|c|c|c|c|}
\hline \multirow{2}{*}{ Variabel } & \multirow{2}{*}{$\mathrm{B}$} & \multicolumn{3}{|c|}{$\begin{array}{l}\text { Collinearity } \\
\text { Statistics }\end{array}$} \\
\hline & & $\begin{array}{l}\text { Toler- } \\
\text { ance }\end{array}$ & VIF & \\
\hline $\begin{array}{l}\text { Kepercayaan } \\
\left(\mathrm{X}_{1}\right)\end{array}$ & 0.207 & $0.039^{*}$ & 0.983 & 1.017 \\
\hline $\begin{array}{l}\text { Pembuatan } \\
\text { keputusan } \\
\text { bersama }\left(\mathrm{X}_{2}\right)\end{array}$ & 0.273 & $0.023^{*}$ & 0.905 & 1.104 \\
\hline $\begin{array}{l}\text { Keterbu- } \\
\text { kaan dalam } \\
\text { komunikasi ke } \\
\text { bawah }\left(\mathrm{X}_{3}\right)\end{array}$ & 0.354 & $0.001^{* *}$ & 0.907 & 1.103 \\
\hline $\begin{array}{l}\text { Mendengarkan } \\
\text { dalam komu- } \\
\text { nikasi ke atas } \\
\left(\mathrm{X}_{4}\right)\end{array}$ & 0.230 & $0.018^{*}$ & 0.890 & 1.124 \\
\hline $\begin{array}{l}\text { Perhatian ter- } \\
\text { hadap tujuan } \\
\text { berkinerja } \\
\text { tinggi }\left(\mathrm{X}_{5}\right)\end{array}$ & 0.214 & $0.037^{*}$ & 0.931 & 1.074 \\
\hline Adjusted R squ & & 0.338 & & \\
\hline
\end{tabular}

Variabel kepercayaan (X1) memiliki nilai signifikansi sebesar 0.039, karena nilai signifikansi tersebut $<0.05$ maka tolak H0 dan terima H1. Dapat disimpulkan bahwa kepercayaan berpengaruh signifikan terhadap kinerja aparatur. Kepercayaan merupakan modal yang penting bagi keberlangsungan hubungan komunikasi di dalam suatu organisasi. Jika tidak ada rasa kepercayaan satu dengan yang lainnya, maka dampak buruk yang mungkin ditimbulkan adalah rasa kecurigaan, merusak kerja sama dalam bekerja, kinerja yang ditunjukkan akan menurun dan pada akhirnya tujuan aparatur itu sendiri tidak sejalan dengan tujuan organisasi.

Variabel pembuatan keputusan bersama (X3) memiliki nilai signifikansi sebesar 0.023 , karena nilai signifikansi tersebut $<0.05$ maka tolak H0 dan terima H1. Dapat disimpulkan bahwa pembuatan keputusan bersama berpengaruh terhadap kinerja aparatur. Mencapai pada standar kinerja yang seragam dengan apa yang dirumuskan pada tujuan organisasi baik dalam bentuk visi, misi, dan sebagainya diperlukan kerja sama dalam memastikan arah organisasi. Kerja sama ini dapat ditunjukkan dengan pengambilan keputusan bersama. Pengambilan keputusan bersama pada Pemerintahan Desa Situ Udik ditunjukkan pada kegiatankegiatan rapat per tiga bulan, pengajian, rapat tahunan atau musrembang, dan pertemuan rutin lainnya.

Variabel keterbukaan dalam berkomunikasi (X3) memiliki nilai signifikansi sebesar 0.001 , karena nilai signifikansi tersebut $<0.05$ maka tolak H0 dan terima H1. Dapat disimpulkan bahwa keterbukaan dalam komunikasi ke bawah berpengaruh terhadap kinerja aparatur. Keterbukaan 
dalam komunikasi ke bawah menjelaskan mengenai kemudahan arus informasi dari atas ke bawah. Artinya bahwa di dalam Pemerintahan Desa Situ Udik arus informasi dari kepala desa ke staf kantor, staf kantor kepada ketua RW, Ketua RW kepada Ketua RT dan lain sebagainya mudah untuk didapatkan tanpa ada banyak yang harus ditutup-tutupi atau dirahasiakan. Antar aparatur dapat langsung menerima informasi secara mudah, lengkap, dan benar yang membuat aparatur merasa terpenuhi informasi yang diperlukan sehingga mampu menunjukkan kinerja yang diperlukan sesuai dengan informasi tersebut.

Variabel mendengarkan dalam berkomunikasi (X4) memiliki nilai signifikansi sebesar 0.018 , karena nilai signifikansi tersebut $<0.05$ maka tolak H0 dan terima H1. Dapat disimpulkan bahwa mendengarkan dalam komunikasi ke atas berpengaruh terhadap kinerja aparatur. Mendengarkan dalam komunikasi ke atas berarti aparatur dalam Pemerintahan Desa Situ Udik memiliki ketertarikan dalam hubungan komunikasi, menaruh perhatian yang fokus terhadap komunikasi tersebut hingga berkeinginan untuk menerima informasi dari bawahan. Variabel perhatian terhadap kinerja tinggi (X5) memiliki nilai signifikansi sebesar 0.037, karena nilai signifikansi tersebut $<0.05$ maka tolak H0 dan terima H1. Dapat disimpulkan bahwa perhatian terhadap tujuan berkinerja tinggi berpengaruh terhadap kinerja aparatur. Tanpa perhatian yang cukup oleh aparatur mengenai pentingnya tugas dan fungsi mereka sebagai pelayanan publik maka kinerja yang dihasilkan akan rendah. Dorongan semangat dalam berbagai bentuk seperti dukungan, insentif, atau penghargaan lainnya cukup penting menurut beberapa aparatur.

Tabel 6. Nilai Signifikansi Pengaruh Iklim Komunikasi Organisasi Terhadap Kinerja Aparatur di Pemerintahan Desa Situ Udik

\begin{tabular}{|c|c|c|}
\hline Variabel & $\begin{array}{l}\text { Sig- } \\
\text { nifikansi }\end{array}$ & Keterangan \\
\hline Kepercayaan & 0.039 & $\begin{array}{l}\text { Signifikan mem- } \\
\text { pengaruhi }\end{array}$ \\
\hline $\begin{array}{l}\text { Pembuatan keputusan } \\
\text { bersama }\end{array}$ & 0.023 & $\begin{array}{l}\text { Signifikan mem- } \\
\text { pengaruhi }\end{array}$ \\
\hline $\begin{array}{l}\text { Keterbukaan dalam } \\
\text { komunikasi ke bawah }\end{array}$ & 0.001 & $\begin{array}{l}\text { Signifikan mem- } \\
\text { pengaruhi }\end{array}$ \\
\hline $\begin{array}{l}\text { Mendengarkan dalam } \\
\text { komunikasi ke atas }\end{array}$ & 0.018 & $\begin{array}{l}\text { Signifikan mem- } \\
\text { pengaruhi }\end{array}$ \\
\hline $\begin{array}{l}\text { Perhatian terhadap } \\
\text { tujuan berkinerja tinggi }\end{array}$ & 0.037 & $\begin{array}{l}\text { Signifikan mem- } \\
\text { pengaruhi }\end{array}$ \\
\hline
\end{tabular}

Pembahasan mengenai pengaruh iklim komunikasi organisasi terhadap kinerja aparatur di Pemerintahan Desa Situ Udik menjelaskan bagian-bagian variabel yang menunjukkan siginifikansi memengaruhi terhadap variabel kinerja. Masing-masing indikator sebagaimana yang telah dijelaskan sebelumnya memiliki nilai signifikansi yang beragam. Hasil nilai signifikansi ini pula memperlihatkan dari masing-masing variabel iklim komunikasi organisasi (kepercayaan, pembuatan keputusan bersama, keterbukaan dalam komunikasi ke bawah, mendengarkan dlam komunikasi ke atas, dan perhatian terhadap tujuan berkinerja tinggi) indikator mana yang memengaruhi sangat signifikan dan mana yang tidak signifikan. Berikut pembahasan yang menjelaskan hal tersebut dapat dilihat juga dalam Tabel 6 .

Tabel 6 menunjukkan bahwa dari seluruh variabel independen yang berjumlah lima, semua memiliki nilai signifikansi $<0.05$. Artinya lima variabel independen tersebut yang terdiri dari kepercayaan, pembuatan keputusan bersama, keterbukaan dalam komunikasi ke bawah, mendengarkan dalam komunikasi ke atas, dan perhatian terhadap tujuan berkinerja tinggi signifikan mempengaruhi variabel dependen yaitu kinerja aparatur di Pemerintahan Desa Situ Udik. Nilai signifikansi terbesar ada pada variabel keterbukaan dalam komunikasi kemudian secara berurutan diikuti oleh variabel mendengarkan dalam komunikasi, pembuatan keputusan bersama, perhatian terhadap berkinerja tinggi, dan kepercayaan

\section{Analisis Pengaruh Pelaksanaan Good Governance terhadap Kinerja Aparatur}

Good governance yang dilaksanakan antar aparatur Pemerintahan Desa Situ Udik dilihat berdasarkan tingkat penerapan transparansi, akuntabilitas, dan kerangka hukum. Masing-masing variabel tersebut dilihat hubungan atau pengaruhnya terhadap kinerja aparatur yang dihitung secara keseluruhan konsep kinerja yaitu prosedur waktu, sarana dan prasarana, kompetensi, waktu penyelesaian, biaya pelayanan, produk pelayanan. Sebagai variabel besar $\mathrm{Y}$, kinerja dihitung secara agregat dari enam indikator yang dijelaskan di atas. Pengujian pelaksanaan tata kelola pemerintahan yang baik (good governance) terhadap kinerja pelayanan publik di Pemerintahan Desa Situ Udik dilakukan dengan analisis regresi linear berganda.

Tabel 7. Hasil Uji Statistik Analisis Regresi Linear Berganda Pengaruh Pelaksanaan Tata Kelola Pemerintahan yang Baik (Good Governance) Terhadap Kinerja Aparatur Di Pemerintahan Desa Situ Udik

\begin{tabular}{|c|c|c|c|c|}
\hline \multirow{2}{*}{ Variabel } & \multirow{2}{*}{ B } & Sig & \multicolumn{2}{|c|}{$\begin{array}{c}\text { Collinearity } \\
\text { Statistics }^{\mathrm{a}}\end{array}$} \\
\hline & & $\begin{array}{l}\text { Toler- } \\
\text { ance }\end{array}$ & VIF & \\
\hline $\begin{array}{l}\text { Transparansi } \\
\left(\mathrm{X}_{1}\right)\end{array}$ & 0.418 & $0.007^{* *}$ & 0.991 & 1.009 \\
\hline $\begin{array}{l}\text { Akuntabilitas } \\
\left(\mathrm{X}_{2}\right)\end{array}$ & 0.209 & $0.043^{*}$ & 0.982 & 1.018 \\
\hline $\begin{array}{l}\text { Kerangka } \\
\text { hukum }\left(\mathrm{X}_{3}\right)\end{array}$ & 0.492 & $0.027^{*}$ & 0.977 & 1.024 \\
\hline \multicolumn{2}{|c|}{$\begin{array}{c}\text { Adjusted R } \\
\text { square }\end{array}$} & \multicolumn{3}{|l|}{0.169} \\
\hline
\end{tabular}

aCollinearity statistics digunakan untuk uji asumsi klasik multikolinearitas yang berfungsi untuk melihat apakah terjadi multikolinearitas pada data yang diuji statistik. Multikolinearitas tidak terjadi jika nilai tolerance $>0.1$ dan nilai VIF $<10$. Kolom collinearity statistics pada Tabel 7 menunjukkan pada data yang diuji tidak terjadi multikolinearitas.

*) Signifikan pada $\alpha<0.05$

**) Signifikan pada $\alpha<0.01$ 
Tabel 7 dapat dilihat dari nilai Adjusted $\mathrm{R}$ square menunjukkan angka 0.169 . Maksudnya bahwa 16.9 persen dari variance kinerja dapat dijelaskan oleh perubahan nilai variabel transparansi, akuntabilitas, dan kerangka hukum yang akan dijelaskan secara lebih rinci pengaruhnya dari tiap variabel pada bagian selanjutnya. Hasil nilai tersebut menyimpulkan bahwa kinerja aparatur di Pemerintahan Desa Situ Udik sebesar 16.9 persen dapat dipengaruhi oleh pelaksanaan tata kelola yang baik (good governance).

Variabel transparansi (X1) memiliki nilai signifikansi sebesar 0.007 , karena nilai signifikansi tersebut $<0.05$ maka tolak H0 dan terima H1. Dapat disimpulkan bahwa transparansi berpengaruh terhadap kinerja aparatur. Transparansi sebagai bagian yang penting dalam penerapan aktivitas pemerintahan yang sehat menunjukkan pengaruhnya terhadap kinerja. Implikasinya adalah masingmasing individu berupaya untuk menyampaikan informasi penting desa secara lengkap dan benar kepada orang-orang yang dituju, misalkan informasi kegiatan rutin rapat per tiga bulan dari staf kantor desa kepada para Ketua RW.

Variabel akuntabilitas (X2) memiliki nilai signifikansi sebesar 0.043, karena nilai signifikansi tersebut $<0.05$ maka tolak H0 dan terima H1. Dapat disimpulkan bahwa akuntabilitas berpengaruh terhadap kinerja aparatur.

Akuntabilitas setiap instansi pemerintah mempunyai kewajiban untuk mempertanggungjawabkan pencapaian organisasinya dalam pengelolaan sumberdaya yang dipercayakan kepadanya. Bentuk laporan-laporan yang harus dipenuhi oleh aparatur memang menjadi suatu pekerjaan sehari-hari. Pengaruh akuntabilitas terhadap kinerja juga dibuktikan pada hasil analisis masing-masing variabel, di mana akuntabilitas dan kinerja sama-sama menunjukkan hasil yang baik. Predikat yang disandang sejak tahun 2008 sebagai desa berprestasi menunjukkan tingkat akuntabilitas yang baik dan berimplikasi pada hasil kinerja yang positif pula.

Tabel 7 dapat dilihat bahwa variabel kerangka hukum (X3) memiliki nilai signifikansi sebesar 0.027 , karena nilai signifikansi tersebut $<0.05$ maka tolak $\mathrm{H} 0$ dan terima $\mathrm{H} 1$. Dapat disimpulkan bahwa kerangka hukum berpengaruh terhadap kinerja aparatur. Kerangka hukum menjadi dasar dalam melakukan aktivitas pemerintahan sesuai dengan tata aturan yang telah ditetapkan dan dilegitimasi oleh semua elemen Pemerintahan Desa Situ Udik. Kinerja yang diinginkan oleh Pemerintahan Desa Situ Udik dapat mengacu pada tata aturan desa yang lengkap dan jelas. Hal ini yang menjadi bukti kerangka hukum berpengaruh terhadap kinerja.

Pembahasan mengenai pengaruh pelaksanaan good governance terhadap kinerja aparatur di Pemerintahan Desa Situ Udik menjelaskan bagian-bagian variabel yang menunjukkan siginifikansi memengaruhi terhadap variabel kinerja. Hasil nilai signifikansi ini pula memperlihatkan dari masing-masing variabel pelaksanaan good governance yang terdiri dari transparansi, akuntabilitas, dan kerangka hukum signifikan atau tidak signifikan memengaruhi kinerja.

Pada Tabel 8 memperlihatkan dari keseluruhan variabel dari konsep besar good governance, semua varibel signifikan memengaruhi (nilai signifikansi $<0.05$ ). Nilai signifikansi untuk variabel transparansi memiliki nilai paling menjauhi
0.05 yang menandakan pengaruh variabel transparansi bisa dikatakan paling dominan di antara dua variabel lainnya.

\section{Tabel 8. Nilai Signifikansi Pengaruh Pelaksanaan Good Governance Terhadap Kinerja Aparatur Di Pemerintahan Desa Situ Udik}

\begin{tabular}{|c|c|c|}
\hline Variabel & $\begin{array}{l}\text { Sig- } \\
\text { nifikansi }\end{array}$ & Keterangan \\
\hline Transparansi & 0.007 & $\begin{array}{l}\text { Signifikan mempen- } \\
\text { garuhi }\end{array}$ \\
\hline Akuntabilitas & 0.043 & $\begin{array}{l}\text { Signifikan mempen- } \\
\text { garuhi }\end{array}$ \\
\hline Kerangka hukum & 0.027 & $\begin{array}{l}\text { Signifikan mempen- } \\
\text { garuhi }\end{array}$ \\
\hline
\end{tabular}

\section{KESIMPULAN DAN SARAN}

\section{Kesimpulan}

Kinerja yang ditunjukkan oleh aparatur Pemerintahan Desa Situ Udik secara umum pada kondisi yang cukup baik. Hal ini menggambarkan bahwa prosedur waktu telah cukup sesuai dengan jadwal yang ada, sarana dan prasarana telah cukup memadai, tingkat kompetensi individu tinggi, waktu dan biaya penyelesaian pelayanan yang normal, dan produk pelayanan yang telah sesuai dengan kebutuhan masyarakat.

Iklim komunikasi organisasi pada Pemerintahan Desa Situ Udik berlangsung positif dengan nilai kepercayaan satu dengan lainnya yang tinggi. Keterbukaan komunikasi yang terlihat dilapangan antar aparatur menggambarkan rasa saling percaya dan terbuka untuk dapat saling berkomunikasi.

Kondisi pelaksanaan tata kelola pemerintahan yang baik atau good governance pada Pemerintahan Desa Situ Udik secara umum berada pada kondisi sedang atau dengan kata lain baik. Kondisi pelaksanaan transparansi termasuk kepada kategori tinggi, akuntabilitas pada kategori sedang dan begitupun pada kerangka hukum.

Hasil keseluruhan iklim komunikasi organisasi, pelaksanaan good governance, dan kinerja menunjukkan pengaruh-pengaruh yang berbeda. Adapun pengaruhpengaruh tersebut yaitu:

1. Iklim komunikasi organisasi pada aparatur Pemerintahan Desa Situ Udik memiliki pengaruh terhadap kinerja aparatur. Pengaruh signifikan terjadi pada variabel kepercayaan, pembuatan keputusan bersama, keterbukaan dalam komunikasi ke bawah, mendengarkan dalam komunikasi ke atas.

2. Pelaksanaan tata kelola pemerintahan yang baik atau good governance pada Pemerintahan Desa Situ Udik memiliki pengaruh terhadap kinerja aparatur. Pengaruh signifikan terjadi pada semua aspek penilaian good governance yaitu transparansi, akuntabilitas, dan kerangka hukum

\section{Saran}

Berdasarkan hasil penelitian yang dilakukan, terdapat beberapa saran yang dapat menjadi pertimbangan 
bagi Pemerintahan Desa Situ Udik yang kaitannya dengan hubungan komunikasi dan kinerjanya saat ini. Mempertahankan hubungan komunikasi yang kondusif antar individu. Keterbukaan komunikasi menjadi hal yang penting untuk membangun kepercayaan satu sama lainnya. Memberikan curahan komunikasi yang seimbang kepada setiap aparatur untuk dapat saling bertukar informasi, memberikan kritik, saran, ide, gagasan dan lain sebagainya.

Sebagaimana kondisi yang ada di lapang bahwa sarana penunjang kerja untuk dapat dirawat sebaik-baiknya, karena bagaimana pun kinerja bukan hanya dilihat dari proses dan hasil kerja individu tapi juga dilihat secara keseluruhan Pemerintahan Desa Situ Udik dalam penyediaan sarana yang baik terutama di kantor desa sebagai gerbang pelayanan kepada warga dan orang-orang yang berkepentingan kedepannya.

Perhatian individu dalam berkinerja tinggi masih cukup banyak yang termasuk dalam kondisi rendah. Artinya, perlu perhatian yang lebih kepada individu apabila tidak bekerja dengan optimal. Kepala desa diharapkan memiliki cara evaluasi kinerja yang efektif guna meningkatkan perhatian aparatur tentang fungsinya dalam masyarakat.

\section{DAFTAR PUSTAKA}

Ambraw H. 2009. Hubungan profil individu, iklim komunikasi organisai dan perilaku komunikasi aparatur dengan pelaksanaan good governance (kasus pada Dinas Pertanian dan Peternakan, Dinas Perkebunan, Dinas Kelautan dan Perikanan Kabupaten Raja Ampat Provinsi Papua Barat). [tesis]. Bogor (ID): Insitut Pertanian Bogor.

Bastaman K. 2010. Pengaruh iklim dan kepuasan komunikasi serta komitmen terhadap kinerja pegawai. Jurnal MIMBAR LPPM Unisba. XXVI (2): 135-136. [Internet]. [diunduh 2013 Sep 28]. Tersedia pada: http://mimbar.lppm.unisba. ac.id/index.php/mimbar/article/view/152/130\#. Una6MnDwmZs

Gustiandri D. 2012. Pengaruh iklim komunikasi organisasi terhadap kinerja pegawai direktorat jenderal pajak pratama kantor pelayanan pajak Serang. [skripsi]. [Internet]. [diunduh 2013 Nov 24]. Serang (ID): Universitas Sultan Ageng Tirtayasa. Tersedia pada: http://repository.fisip-untirta.ac.id/199/1/ SKRIPSI\%20KOM\%20-\%20Diskatiya \%20 Gustiandri\%20072887.pdf

Masmuh A. 2010. Komunikasi organisasi dalam perspektif teori dan praktek. Malang (ID): UMM Press. 324 hlm.

[Menpan] Menteri Pendayagunaan Aparatur Negara dan Reformasi Birokrasi. 2013. Akuntabilitas kinerja kabupaten/kota makin meningkat. [Internet]. [diunduh: 2013 Des 1]. Tersedia pada: http://www. menpan.go.id/berita-terkini/1024-akuntabilitaskinerja-kabupaten-kota-makin-meningkatakuntabilitas-kinerja-kabupaten-kota-makinmeningkat-akuntabilitas-kinerja-kabupaten-kotamakin-meningkat.

Kep. Men. PAN No: 63 Tahun
2003 tentang prinsip pelayanan publik. [Internet]. [diunduh 2013 Des 1]. Tersedia pada: http://www. menpan.go.id/pelayanan-publik/593-produkhukum7

. Keputusan Menteri Pendayagunaan Aparatur Negara Nomor: KEP/25/M.PAN/2/2004. [Internet]. [diunduh 2013 Des 1]. Tersedia pada: http://www.menpan.go.id/pelayanan-publik/593produk-hukum7

Mulyadi A. 2013. Analisis pengaruh perilaku birokrasi dan budaya kerja terhadap kinerja pegawai pada unit pelayanan pengadaan barang dan jasa Provinsi Jawa Barat. [disertasi]. [Internet]. [diunduh 2013 Okt 30]. Bandung (ID): Universitas Pasundan. Tersedia pada: http://digilib.unpas.ac.id/files/disk1/47/ jbptunpaspp-gdl-drhachmadm-2350-1-achmadm-7. pdf

Mulyana D. 2005. Ilmu komunikasi: suatu pengantar. Bandung (ID): Rosda. $410 \mathrm{hlm}$.

Nurlita I. 2012. Investigation of organizational communication climate at Bhayangkara Surabaya University using communication climate inventory (CCI) method. Savap International Journal. 3 (2): 259-264. [Internet]. [diunduh 2013 Nov 1]. Tersedia pada: http://www.savap.org.pk/journals/ARInt./ Vol.3(2)/2012(3.2-33).pdf

Pace RW, Faules DF. 2006. Komunikasi organisasi. Dalam: Mulyana D, editor. Komunikasi organisasi: strategi meningkatkan kinerja perusahaan. Bandung (ID): PT. Remaja Rosdakarya. $566 \mathrm{hlm}$.

Pemerintahan Desa Situ Udik. 2008. Peraturan Desa Situ Udik Nomor 5 Tahun 2008 tentang Pembentukan Lembaga Kemasyarakatan Desa. Bogor [ID]: Pemerintahan Desa Situ Udik.

2009. Peraturan Desa Situ Udik Nomor 2 Tahun 2009 tentang Organisasi dan Tata Kerja Pemerintahan Desa Situ Udik. Bogor (ID): Pemerintahan Desa Situ Udik.

Prasetyani H. 2009. Analisis kinerja pelayanan publik perusahaan daerah air minum (PDAM) Kabupaten Demak. [tesis]. [Internet]. [diunduh 2013 Nov 24]. Semarang (ID): Universitas Diponegoro. Tersedia pada: eprints.undip.ac.id/18637/1/NURUL_ PRASETYANI.pdf

SanusiA.2012.Pengaruhmotivasikerjadaniklimkomunikasi organisasi terhadap komitmen keorganisasian pegawai arsip nasional Republik Indonesia. [tesis]. [Internet]. [diunduh 2013 Sep 28]. Depok [ID]: Universitas Indonesia. Tersedia pada: http:// lontar.ui.ac.id/file?file=digital/20313832-T\%20 31750-Pengaruh\%20motivasi-full\%20text.pdf

Singarimbun M, Effendi S. 1989. Metode penelitian survai. Effendi S, editor. Jakarta (ID): LP3S. $336 \mathrm{hlm}$.

World Bank. 2008. Mengoptimalkan kontribusi desentralisasi bagi pembangunan: metodologi kerangka kerja pengukuran kinerja pemerintah 
daerah (LPGM). [laporan makalah]. [Internet]. [diunduh 2013 Des 1]. Jakarta: World Bank. Hal 1-42. Tersedia pada: http://www-wds.worldbank.org/ external/default/WDSContentServer/WDSP/IB/20 08/12/31/000334955_20081231034617/Rendered/ DF/470090BAHASAŌW1blic10LGPM1indonesia. pdf

Wijaya T. 2009. Analisis data penelitian menggunakan spss. Yogyakarta [ID]: Universitas Atma Jaya Yogyakarta. Hlm 100.

Yoanne B. 2013. Pengaruh iklim komunikasi organisasi PT. Djarum Super Cooking Oil Surabaya terhadap kinerja karyawan. Jurnal E-Komunikasi Universitas Kristen Petra Surabaya. [Internet]. [diunduh 2013 Sep 28]. Surabaya (ID): Universitas Kristen Petra. 1 (3): 242-251. Tersedia pada: http://studentjournal. petra.ac.id/index.php/ilmu-komunikasi/article/ view/938/838. 